\title{
SISTEM PAKAR DIAGNOSA PENYAKT TIROID MENGGUNAKAN METODE DEMPSTER SHAFER
}

\author{
Chairun Nas \\ Manajemen Informatika, STMIK Catur Insan Cendikia \\ Jl. Kesambi No.202, Cirebon, Jawa Barat \\ email: chairun.nas@cic.ac.id
}

\begin{abstract}
Abstrak
Penyakit tiroid merupakan gangguan pada kelenjer tiroid yang terletak dibagian leher tepatnya dibawah jakun. Saat ini masyarakat sering tidak memperhatikan kesehatan makanan yang dikonsumsi, sehingga dapat menimbulkan penyakit tiroid. Tujuan dari penelitian ini membantu dalam mendiagnosa penyakit tiroid yang dialami oleh pasien dengan menggunakan sistem pakar. Sistem pakar akan mengelola data penyakit dan gejala penyakit pada pasien dengan melakukan pengujian menggunakan metode Dempster Shafer. Hasil dari pengujian metode Dempster Shafer ini adalah dihasilkan sebuah diagnosa terhadap suatu penyakit tiroid dengan nilai densitas sebesar 97,6\%. Maka metode ini dapat digunakan untuk mendiagnosa penyakit tiroid yang dialami oleh pasien sehingga membantu dokter spesialis mengambil keputusan dalam penanganan penyakit.
\end{abstract}

Kata Kunci: Kecerdasan Buatan, Sistem Pakar, Diagnosa, Tiroid, Dempster Shafer

\begin{abstract}
Thyroid disease is a disorder of the thyroid gland which is located in the neck precisely below the Adam's apple. At present the community often does not pay attention to the health of food consumed, so it can cause thyroid disease. The purpose of this study helps in diagnosing thyroid disease experienced by patients using an expert system. The expert system will manage the disease data and symptoms of the disease in patients by testing using the Dempster Shafer method. The results of testing the Dempster Shafer method are a diagnosis of a thyroid disease with a density value of 97.6\%. So this method can be used to diagnose thyroid disease experienced by patients so as to help specialist doctors make decisions in handling further diseases.
\end{abstract}

Keywords: Artificial Intelligence, Expert System, Diagnosis, Thyroid, Dempster Shafer

\section{PENDAHULUAN}

Penyakit adalah suatu keadaan abnormal dari tubuh atau pikiran yang menyebabkan ketidaknyamanan, disfungsi atau kesukaran terhadap orang yang dipengaruhinya. Dewasa ini, kadang kita terlalu sibuk dengan kegiatan sehingga mengabaikan kesehatan yang dapat menimbulkan berbagai macam penyakit. Salah satu penyakit yang muncul akibat kurangnya perhatian terhadap kesehatan adalah penyakit tiroid. Penyakit tiroid adalah sejenis kanker yang sel-sel kanker berkembang biak di dalam jaringan tiroid [1]. Pendiagnosaan penyakit tiroid sulit untuk dilakukan karena gejala penyakit tiroid bisa bermacam-macam tergantung pada naik dan turunnya hormon tiroid yang meningkatkan penggunaaan oksigen oleh sel-sel tubuh [2]. Dalam hal ini dibutuhkan pemeriksaan tiroid oleh dokter serta interpretasi data klinis yang tepat untuk mendiagnosa penyakit tiroid. Namun keterbatasan seorang dokter diakibatkan oleh faktor usia dan keterbatasan waktu menyebabkan kurangnya interprestasi 
data klinis seorang pasien. Maka untuk mengatasi masalah tersebut, dibutuhkan suatu sistem pakar yang mampu mendiagnosa penyakit tiroid berdasarkan data klinis pasien.

Sistem pakar merupakan sistem berbasis komputer yang menggunakan pengetahuan, fakta dan teknik penalaran dalam memecahkan masalah yang biasanya hanya dapat dipecahkan oleh seorang pakar di bidang tersebut [3]. Dalam sistem pakar digunakan teknik penalaran atau metode yang mampu melakukan perhitungan secara matematis sehingga memberikan hasil diagnosa yang tepat. Salah satu Metode yang digunakan pada sistem pakar adalah metode Dempster-Shafer. Dempster-Shaferadalah suatu teori matematika untuk pembuktian berdasarkan belief functions and plausible reasoning (fungsi kepercayaandan pemikiran yang masuk akal), yang digunakanuntuk mengkombinasikan potongan informasi yang terpisah untuk mengkalkulasi kemungkinandari suatu peristiwa [4].

Penggunaan metode Dempster Shafer telah dilakukan pada pendiagnosaan penyakit yang diakibatkan oleh bakteri Salmonella. Penelitian ini menggunakan 8 jenis penyakit dan 23 gejala penyakitnya. Dalam menghitung nilai Dempster Shafer, digunakan nilai believe yang telah ditentukan untuk setiap gejala yang selanjutnya dilakukan perhitungan nilai densitas baru untuk beberapa kombinasi. Hasil akhir dari sistem pakar dengan menggunakan metode ini adalah ditemukan sebuah penyakit dengan nilai kepastian sebesar $77,2 \%$ [5]. Sehingga metode ini memiliki tingkat kepastian yang tinggi dalam pendiagnoosaan sebuah penyakit.

Pada penelitian tentang penyakit tiroid sebelumnya, sistem pakar diagnosa penyakit tiroid diimplementasikan dengan menggunakan metode Naive Bayes. Penelitian ini menggunakan 5 jenis data penyakit tiroid dengan 33 gejala penyakitnya. Metode Naive Bayes menghitung probabilitas serta kemungkinan dari penyakit dan gejala-gejala yang timbul berdasarkan nilai yang diberikan oleh pakar.Hasil dari sistem pakar ini adalah dihasilkan nilai probabilitas setiap jenis penyakit yang ada pada penyakit tiroid [2]. Namun dalam penggunaan metode Naive Bayes masih ditemukan kekurangan disebabkan metode ini menghitung peluang kemungkinan terjadinya penyakit tiroid, sehingga hasil sistem pakar memiliki perbandingan yang jauh dengan hasil diagnosa dokter.

Dari penelitian yang telah dibahas sebelumnya, maka metode Dempster Shafer sangat cocok digunakan dalam perancangan sistem pakar untuk menentukan tingkat keyakinan dalam pendiagnosaan penyakit tiroid.

\section{TINJAUAN PUSTAKA}

\subsection{Kecerdasan Buatan}

Kecerdasan buatan adalah suatu cabang ilmu pengetahuan yang berhubungan dengan pemanfaatan mesin untuk memecahkan persoalan yang rumit dengan cara yang lebih manusiawi [6]. Komputer pada awalnya berfungsi sebagai sebagai alat hitung, namun seiring perkembangan zaman, komputer dibutuhkan dan diberdayakan untuk mengerjakan segala sesuatu yang bisa dikerjakan oleh manusia. Maka pada tahun 1956 pada Dartmouth Conference dikenalkan kecerdasan buatan oleh seorang profesor dari MIT bernama John McCarthy [7].

Kecerdasan buatan atau Artificial Inteligence (AI) membuat komputer agar dapat melakukan pekerjaan seperti yang dilakukan oleh manusia. Adapun kecerdasan buatan dipelajari dalam bidang-bidang seperti: Robotics, Computer Vision, Artificial Neural System, Natural Language Processing, Speech Recognition dan Expert System[5]. Untuk membuat sistem yang memiliki kecerdasan buatan, dibutuhkan 2 bagian utama, yaitu [7]: 
1. Basis Pengetahuan (Knowledge Base) yaitu berisi fakta-fakta, teori, pemikiran dan hubungan antara satu dengan yang lainnya.

2. Motor Inferensi (Inference Engine) yaitu kemampuan menarik kesimpulan berdasarkan pengalaman.

\subsection{Sistem Pakar}

Sistem pakar merupakan cabang dari kecerdasan buatan yang membuat ekstensi untuk spesialisasi pengetahuan guna memecahkan suatu permasalahan pada Human Expert[8]. Human Expert merupakan seorang ahli dalam suatu bidang ilmu pengetahuan tertentu dimana permasalahan pada bidang tersebut tidak semua orang dapat menyelesaikan atau mengatasinya. Selain dari itu, sistem pakar dapat diartikan sebagai sistem yang berusaha mengadopsi pengetahuan manusia ke dalam komputer, agar komputer dapat menyelesaikan suatu permasalahan tertentu dengan meniru kerja dari para ahli [3]. Sehingga dengan adanya sistem pakar, maka setiap orang dapat menyelesaikan masalah rumit seperti halnya seorang pakar, dan bagi para ahli sistem pakar dapat membantu sebagai asisten dalam aktivitasnya.

Sistem pakar merupakan bagian dari perangkat lunak tingkat tinggi atau pemograman tingkat tinggi yang berupaya menduplikasi fungsionalitas dari seorang pakar yang memiliki keahlian atau area tertentu [9]. Aplikasi sistem pakar disusun oleh dua bagian utama, yaitu lingkungan pengembang (Development Environment) yang berguna untuk memasukkan pengetahuan pakar kedalam lingkungan sistem pakar, sedangkan lingkungan konsultasi (Consultation Environment) berguna untuk memperoleh pengetahuan dari pakar [4]. Implementasi sistem pakar banyak digunakan untuk kepentingan komersial disebabkan sistem pakar dipandang sebagai cara penyimpanan pengetahuan pakar ke dalam program, sehingga komputer dapat melakukan penalaran secara cerdas.

\subsection{Dempster Shafer}

Dempster Shafer adalah teori matematika untuk mencari bukti berdasarkan fungsi keyakinan dan alasan yang masuk akal untukdigunakan dalam menggabungkan informasi yang terpisah (bukti) dan menghitung probabilitas suatu peristiwa [9]. Metode Dempster Shafer dikenalkan oleh Dempster yang melakukan percobaan model ketidakpastian dengan rangeprobabilities dari pada sebagai probabilitas tunggal. Pada tahun 1976, Shafer mempublikasikan teori yang dikenalkan oleh Dempster pada sebuah buku yang berjudul Mathematical Theory Of Evidentdimana pada teori tersebut dapat membedakan ketidakpastian dan ketidaktahuan [3]. Banyak metode atau model yang lengkap dan konsisten dalam menentukan ketidakpastian, namun kenyataannya banyak masalah yang tidak bisa diselesaikan sepenuhnya dan konsisten.Ketidakkonsistenan ini disebabkan oleh penambahan fakta baru yang disebutkan dengan nonmonotonik. Hal ini yang membuat metode Dempster Shafer memiliki kelebihan dalam mengatasi ketidakkonsistenan.

Secara umum teori Dempster Shafer ditulis dalam suatu interval Belief dan Plausibility. Belief (Bel) adalah ukuran kekuatan evidence dalam mendukung suatu himpunan proposisi. Jika bernilai 0 maka mengindikasikan bahwa tidak ada evidence, dan jika bernilai 1 maka menunjukan adanya kepastian. Sedangkan Plausibility (Pls) akan mengurangi tingkat kepastian dari evidence[5]. Menurut Giarranto dan Rilley fungsi Belief dapat diformulakan sebagai berikut:

$$
\operatorname{Bel}(X)=\sum_{Y \subseteq X} m(Y)
$$


Keterangan:

$\operatorname{Bel}(\mathrm{X}) \quad: \operatorname{Belief}(\mathrm{X})$

$\mathrm{m}(\mathrm{Y}) \quad: \mathrm{m}(\mathrm{Y})=$ mass function dari $(\mathrm{Y})$

Sedangkan Plausibility (Pls) diformulakan sebagai berikut:

$$
\operatorname{Pls}(X)=1-\operatorname{Bel}\left(X^{\prime}\right)=1-\sum_{Y \subseteq X} m\left(X^{\prime}\right)
$$

Keterangan:

$\begin{array}{ll}\operatorname{Bel}\left(\mathrm{X}^{\prime}\right) & \text { : Belief }(\mathrm{X}) \\ \mathrm{Pls}(\mathrm{X}) & : \text { Plausibility }(\mathrm{X}) \\ \mathrm{m}\left(\mathrm{X}^{\prime}\right) & \text { : mass function dari }(\mathrm{X}) \\ \mathrm{m}(\mathrm{Y}) & \text { : mass function dari }(\mathrm{Y})\end{array}$

Plausibility bernilai 0 sampai 1. jikakita yakin akan X' maka dapat dikatakan Belief $\left(\mathrm{X}^{\prime}\right)=1$ sehingga dari rumus diatas nilai Pls $(\mathrm{X})=0$. Beberapa kemungkinan range antara Belief dan Plausibility ditunjukkan pada Tabel 1 [4].

Tabel 1. Range Belief dan Plausibility

\begin{tabular}{ll}
\hline Kemungkinan & Keterangan \\
\hline$[1,1]$ & Semua Benar \\
{$[0,0]$} & Semua Salah \\
{$[0,1]$} & Ketidakpastian \\
{$[\mathrm{Bel}, 1]$ where $0<\mathrm{Bel}<1$} & Cenderung Mendukung \\
{$[0, \mathrm{Pls}]$ where $0<\mathrm{Pls}<1$} & Cenderung Menolak \\
{$[\mathrm{Bel}, \mathrm{Pls}]$ where $0<\mathrm{Bel} \leq \mathrm{Pls}<1$} & Cenderung Mendukung dan Menolak \\
\hline
\end{tabular}

Dalam Dempster Shafer terdapat Frame Of Discrement yang dinotasikan dengan simbol $(\Theta)$ yang merupakan semesta pembicara dari sekumpulan hipotesis sehingga sering disebut dengan environment, yang dapat ditunjukkan pada persaman [3]:

$$
\Theta=\{\theta 1, \theta 2, \ldots \ldots \theta \mathrm{n}\}
$$

Keterangan:

$\Theta \quad$ : FOD atau environment

$\theta 1, \ldots . . .0 \mathrm{n} \quad:$ Element/unsur bagian dalam environment

Environment memiliki elemen yang menjelaskan kemungkinan sebagai jawaban yang hanya ada satu jawaban yang sesuai dengan yang dibutuhkan. Kemungkinan itu disebut dengan power set yang dinotasikan dengan $\mathrm{P}(\Theta)$, setiap element dalam power set memiliki nilai interval antara 0 sampai 1 . Maka $\mathrm{m}: \mathrm{P}(\Theta) \rightarrow[0,1]$, makan dapat dirumuskan:

$$
\sum_{X e P(} m(X)=1
$$

Mass function (m) merupakan tingkat kepercayaan dari suatu evidence yang sering disebut evidence measure. Tujuannya adalah mengaitkan ukuran keperyacaan elemenelemen $\theta$. Tidak semua evidence secara langsung mendukung tiap-tiap elemen, maka perlu adanya probabilitas fungsi densitas $(\mathrm{m})$. Nilai $\mathrm{m}$ tidak hanya mendefenisikan elemen- 
elemen $\theta$ saja, namun juga semua subsetnya sehingga ditujukan bahwa semua (m) dalam subset $\theta$ sama dengan 1. Apabila ada informasi hipotesis, maka $m\{\theta\}=1-(\mathrm{m})$ dan jika tidak ada informasi apapun untuk memilih hipotesis tersebut, maka nilai $\mathrm{m}\{\theta\}=1,0$ [5].

Pada aplikasi sistem pakar terdapat sejumlah evidence yang akan digunakan pada faktor ketidakpastian dalam hasil diagnosa. Untuk mengatasi sejumlah evidence tersebut, digunakan aturan Dempster's Rule of Combination, dimana secara umum menggunakan rumus [4]:

$$
m 1 \oplus m 2(Z)=\frac{\sum_{X \cap Y=Z} m 1(X) \cdot m 2(Y)}{1-\sum_{X \cap Y=\phi} m 1(X) \cdot m 2(Y)}
$$

Keterangan:

$m 1 \oplus m 2(Z) \quad$ : mass function dari evidence $(\mathrm{Z})$

$m 1 \quad:$ mass function dari evidence $(\mathrm{X})$

m2 : mass function dari evidence $(\mathrm{Y})$

\subsection{Gejala Penyakit Tiroid}

Penyakit tiroid adalah berbagai macam gangguan atau masalah yang terjadi dan timbul pada kelenjar tiroid dimana terletak dibawah jakun [2]. Kelenjar tiroid berfungsi mengatur berbagai sistem metabolisme dalam tubuh sehingga memiliki peranan yang sangat penting. Perubahan fungsi tiroid dapat menimbulkan perubahan pada suasana hati. Gangguan fungsi tiroid dan diketahui dari perubahan kadar tiroid dan perubahan Thyroid Stimulation Hormone (TSH) didalam darah [10]. Perubahan fungsi tiroid akan menimbulkan gejala gangguan fungsi kognitif, perilaku dan perubahan perasaan serta kecemasan. Hal ini disebabkan karena hormon tiroid mengalami kelebihan atau kekurangan pada tubuh kita [2].

Kelebihan atau kekurangan hormon tiroid didalam tubuh secara umum akan menyebabkan gejala seperti metabolisme didalam tubuh meningkat secara signifikan, penurunan berat badan yang mendadak, detak jantung yang cepat atau tidak teratur, berkeringat serta gugup atau mudah marah [11]. Gejala umum tersebut biasanya dapat menjadi gejala awal munculnya penyakit tiroid didalam tubuh. Namun penyakit tiroid bisa sulit di diagnosis karena gejalanya mudah dikacaukan dengan kondisi lain didalam tubuh [12]. Gejala dari penyakit tiroid dapat diatasi dan dikendalikan apabila gejala penyakit tiroid dapat dikenali sejak dini, sehingga mengurangi adanya tekanan dari gejala-gejala penyakit tiroid lainnya.

\section{METODE PENELITIAN}

Dalam penelitian ini, dapat diuraikan kerangka kerja dari penelitian yang dapat dijelaskan pada Gambar 1 berikut: 


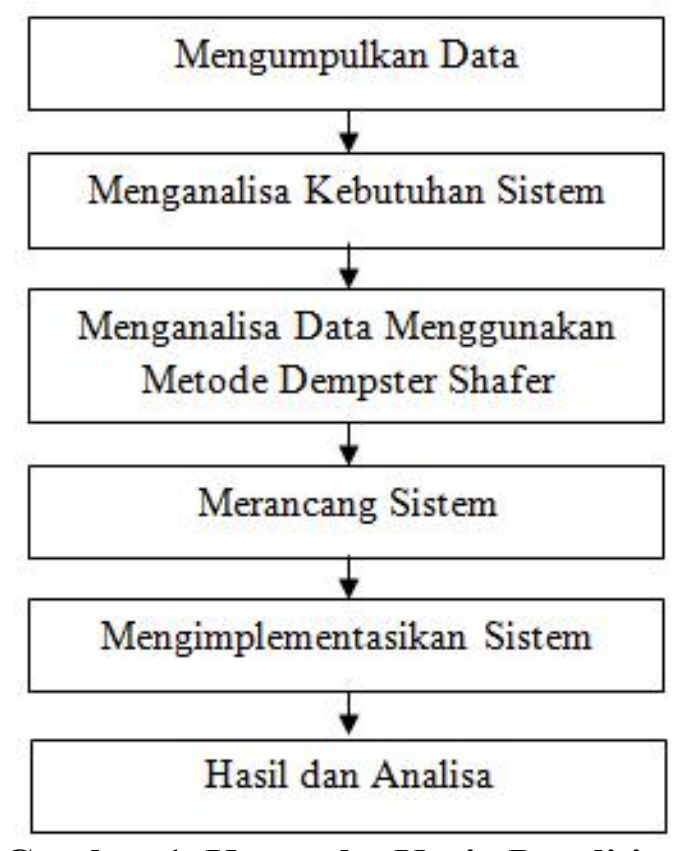

Gambar 1. Kerangka Kerja Penelitian

Pada Gambar 1 menjelaskan proses dalam pembangunan sistem pakar untuk pendiagnosaan penyakit tiroid. Maka dapat dijelaskan tahapan tersebut sebagai berikut:

\section{a. Mengumpulkan Data}

Pengumpulan data dalam penelitian ini dilakukan dengan melakukan wawancara bersama dokter spesialis. Dari hasil wawancara tersebut, didapatkanlah 4 jenis penyakit tiroid dengan 26 gejala penyakitnya dan hubungan antara penyakit dan gejala beserta belief masing-masing gejala. Adapun data penyakit yang diperoleh dilihat pada Tabel 2 berikut:

Tabel 2. Data Penyakit

\begin{tabular}{cl}
\hline Kode Penyakit & \multicolumn{1}{c}{ Nama Penyakit } \\
\hline P001 & Hipotiroidisme \\
P002 & Hipertiroidisme \\
P003 & Radang Tiroid (Hashimoto) \\
P004 & Kanker Tiroid \\
\hline
\end{tabular}

Sedangkan data gejala penyakit dan hubungannya dengan penyakit (Rule) beserta nilai belief dan Plausibility yang telah diperoleh dijelaskan pada Tabel 3 berikut:

Tabel 3. Rule Gejala Penyakit dan Data Penyakit Beserta Belief dan Plausibility

\begin{tabular}{|c|c|c|c|c|c|c|c|}
\hline \multirow{2}{*}{$\begin{array}{l}\text { Kode } \\
\text { Gejala }\end{array}$} & \multirow{2}{*}{ Nama Gejala } & \multicolumn{4}{|c|}{ Penyakit } & \multirow{2}{*}{ Belief } & \multirow{2}{*}{ Plausibility } \\
\hline & & P001 & P002 & P003 & P004 & & \\
\hline G001 & Tenggorokan kering & $*$ & & & & 0,4 & 0,6 \\
\hline G002 & Wajah bengkak & $*$ & & $*$ & & 0,3 & 0,7 \\
\hline G003 & Kulit kering & * & & $*$ & & 0,6 & 0,4 \\
\hline G004 & Berat badang naik tanpa sebab & * & & $*$ & & 0,6 & 0,4 \\
\hline G005 & Mudah lelah dan letih & $*$ & & $*$ & & 0,6 & 0,4 \\
\hline G006 & Konsentrasi buruk & $*$ & * & $*$ & & 0,6 & 0,4 \\
\hline G007 & Depresi & * & & $*$ & & 0,1 & 0,9 \\
\hline G008 & Detak jantung melambat & $*$ & & $*$ & & 0,6 & 0,4 \\
\hline G009 & Lemah otot & $*$ & & & & 0,4 & 0,6 \\
\hline G010 & Kadar kolesterol dala darah meningkat & $*$ & & $*$ & & 0,8 & 0,2 \\
\hline G011 & Rambut rontok & * & * & & & 0,6 & 0,4 \\
\hline
\end{tabular}


Hal : 1 - 14

\begin{tabular}{|c|c|c|c|c|c|c|}
\hline G012 & Pengkatan tekanan darah & $*$ & & & 0,8 & 0,2 \\
\hline G013 & Gugup & $*$ & & & 0,8 & 0,2 \\
\hline G014 & Tremor (Gemetaran) & $*$ & & & 0,8 & 0,2 \\
\hline G015 & Sering berkeringat & $*$ & & & 0,8 & 0,2 \\
\hline G016 & Gelisah & $*$ & & & 0,6 & 0,4 \\
\hline G017 & Sering BAB (melebihi normal) & $*$ & & & 0,6 & 0,4 \\
\hline G018 & Siklus menstruasi tidak teratur & $*$ & $*$ & & 0,3 & 0,7 \\
\hline G019 & Denyut jantung tidak teratur & $*$ & & & 0,8 & 0,2 \\
\hline G020 & Sulit tidur & $*$ & & & 0,6 & 0,4 \\
\hline G021 & Kelenjar tiroid membesar & $*$ & & & 0,9 & 0,1 \\
\hline G022 & Kesulitan hamil & & $*$ & & 0,7 & 0,3 \\
\hline G023 & Tenggorokan sakit dan terasa penuh & & & $*$ & 0,3 & 0,7 \\
\hline G024 & Suara serak dan memburuk dalam beberapa minggu & & & $*$ & 0,5 & 0,5 \\
\hline G025 & Rasa sakit pada bagian leher & & & * & 0,6 & 0,4 \\
\hline G026 & Pembengkakan kelenjar getah bening dileher & & & * & 0,9 & 0,1 \\
\hline
\end{tabular}

Nilai belief dan plausibility diperoleh dari keterangan dokter yang diukur melalui seberapa besar nilai keyakinan dokter terhadap suatu gejala penyakit tiroid untuk suatu jenis penyakit tiroid. Besaran nilai keyakinan tersebut dapat diukur dari range nilai 0 sampai 1 , semakin nilai keyakinan suatu gejala mencapai nilai 1, maka semakin besar nilai keyakinannya. Maka semakin besar nilai belief suatu gejala terhadap satu penyakit, semakin besar gejala tersebut dapat mempengaruhi penyakit tiroid.

\section{b. Menganalisa Kebutuhan Sistem}

Analisa kebutuhan sistem menguraikan setiap kebutuhan yang akan digunakan dalam membangun sistem pakar seperti, kebutuhan data, kebutuhan perancangan, kebutuhan implementasi dan lain-lain.

\section{c. Menganalisa Data}

Setelah melakukan proses pengumpulan data, selanjutnya dilakukan proses analisa data dengan menggunakan metode Dempster Shafer yang nantinya akan diimplementasikan kedalam sistem pakar.

\section{d. Merancang Sistem}

Perancangan sistem dilakukan dengan menggunakan Unified Modeling Langguage (UML) yang memberikan kemudahan memindahkan konsep sistem yang dirancang ke dalam bentuk program aplikasi. Dalam penelitian ini, aplikasi sistem pakar memiliki hubungan antara user dan sistem yang dapat dirancang dengan menggunakan Use Case Diagram seperti pada Gambar 2 berikut:

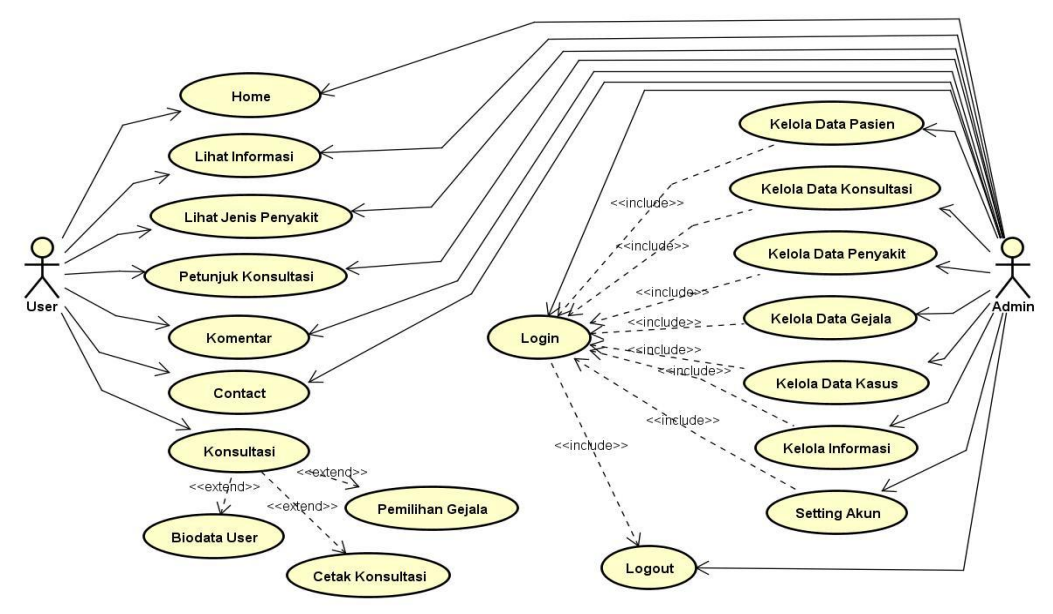




\section{Gambar 2. Perancangan Use Case Diagram}

Sedangkan untuk mengambarkan hubungan data dalam sistem (Database) dapat dirancang dengan menggunakan Class Diagram pada Gambar 3 Berikut:

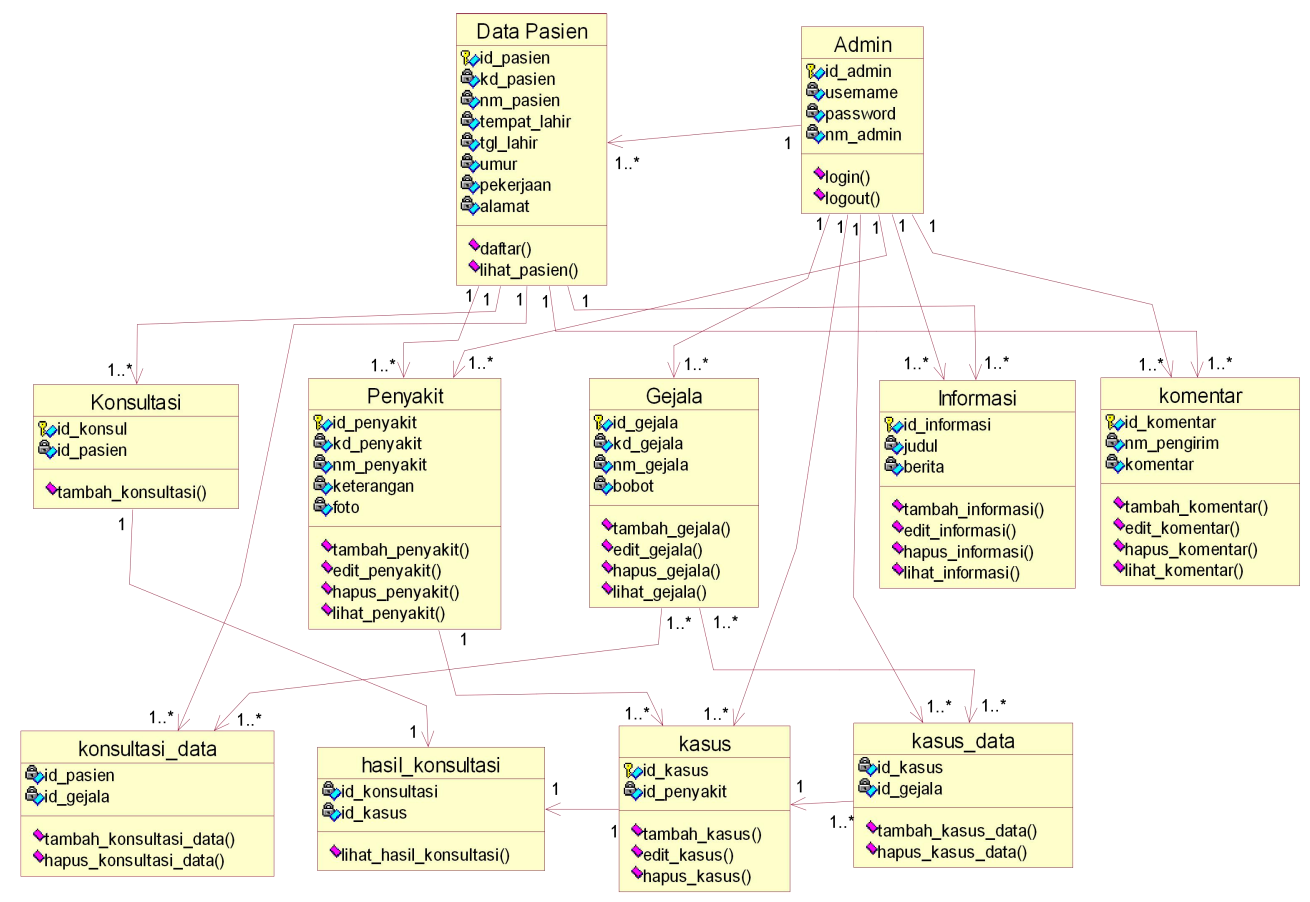

Gambar 3. Perancangan Class Diagram

\section{e. Implementasi Sistem}

Implementasi sistem pada penelitian ini akan diimplementasikan dalam pemograman web. Sehingga user dapat mengakses sistem dimanapun dan kapanpun dengan menggunaan perangkat laptop ataupun smartphone

\section{HASIL DAN PEMBAHASAN}

\subsection{Pengujian Metode Dempster Shafer}

Pembahasan dalam penelitian ini adalah melakukan uji coba metode Dempster Shafer untuk dapat melakukan pendiagnosaan penyakit tiroid dengan gejala yang dialami oleh pasien agar metode Dempster Shafer dapat diimplementasikan kedalam sistem pakar. Adapun data gejala pasien yang akan dilakukan pengujian dapat dilihat pada Tabel 4 :

Tabel 4. Data Uji Gejala Pasien

\begin{tabular}{cl}
\hline Kode Gejala & \multicolumn{1}{c}{ Nama Gejala } \\
\hline G014 & Tremor (Gemetaran) \\
G015 & Sering Berkeringat \\
G006 & Konsentrasi Buruk \\
G011 & Rambu Rontok \\
G016 & Gelisah \\
\hline
\end{tabular}

Selanjutnya dari gejala tersebut, ditentukan nilai belief dan plausibility seperti pada Tabel 3. Maka proses Dempster Shafer dapat dilakukan seperti berikut:

1. Tentukan tingkat keyakinanM1 dan M2 untuk mengahasilkan M3. 
Fakta 1 : G014 (M1)merupakan gejala penyakit dari Hipertiroidisme (P002), maka dapat ditentukan nilai belief dan plausibility berikut:

Nilai belief $\mathrm{M} 1(\mathrm{G} 014) \quad=0,8$

Nilai Plausibility $\mathrm{M} 1(\theta) \quad=1-0,8=0,2$

Fakta 2 : G015 (M2) merupakan gejala penyakit dari Hipertiroidisme (P002), maka dapat ditentukan nilai belief dan plausibility berikut:

Nilai belief $\mathrm{M} 2(\mathrm{G} 015) \quad=0,8$

Nilai Plausibility M2 $(\theta) \quad=1-0,8=0,2$

Selanjutnya hitung densitas baru untuk kombinasi M3 seperti pada Tabel 5:

Tabel 5. Densitas Baru untuk M3

\begin{tabular}{lll}
\hline & M2 $\{$ P002 $\} \mathbf{0 , 8}$ & M2 $\{\boldsymbol{\theta}\} \mathbf{0 , 2}$ \\
\hline M1 $\{$ P002 $\} \mathbf{0 , 8}$ & $\{$ P002 $\} 0,64$ & $\{\mathrm{P} 002\} 0,16$ \\
M1 $\{\boldsymbol{\theta}\} \mathbf{0 , 2}$ & $\{\mathrm{P} 002\} 0,16$ & $\{\theta\} 0,04$ \\
\hline
\end{tabular}

Maka selanjutnya dapat dihitung tingkat keyakinan M3 sebagai berikut:

Nilai belief $M 3\{P 002\}=\frac{(0.64+0.16+0.16)}{1-0}=0.96$

Nilai Plausibility $M 3\{\Theta\}=\frac{(0.04)}{1-0}=0.04$

Maka nilai keyakinan terhadapat penyakit Hipertiroidisme (P002) dari gejala G014 dan G015 yaitu sebesar 96\%.

2. Tentukan nilai keyakinan M3 dan M4 untuk menghasilkan M5.

Fakta 3 : G006 (M4) merupakan gejala penyakit dari Hipotiroidisme (P001), Hipertiroidisme (P002) dan Radang Tiroid (P003), maka dapat ditentukan nilai belief dan plausibility berikut:

Nilai belief M4(G006) $\quad=0,6$

Nilai Plausibility M4 $(\theta) \quad=1-0,6=0,4$

Selanjutnya hitung densitas baru untuk kombinasi M5 seperti pada Tabel 6:

Tabel 6. Densitas Baru untuk M5

\begin{tabular}{lll}
\hline & M4 $\{$ P001, P002, P003 $\}$ 0,6 & M4 $\{\boldsymbol{\theta}\} \mathbf{0 , 4}$ \\
\hline M3 $\{$ P002 $\}$ 0,96 & $\{\mathrm{P} 002\} 0,576$ & $\{\mathrm{P} 002\} 0,384$ \\
M3 $\{\boldsymbol{\theta}\} \mathbf{0 , 0 4}$ & $\{\mathrm{P} 001, \mathrm{P} 002, \mathrm{P} 003\} 0,024$ & $\{\theta\} 0,0016$ \\
\hline
\end{tabular}

Maka selanjutnya dapat dihitung tingkat keyakinan M5 sebagai berikut:

Nilai belief $M 5\{P 002\}=\frac{(0.576+0.384)}{1-0}=0.96$

Nilai belief $M 5\{P 001, P 002, P 003\}=\frac{(0.024)}{1-0}=0.024$

Nilai Plausibility $M 5\{\Theta\}$ $=\frac{(0.04)}{1-0}=0.0016$

Maka nilai keyakinan terhadap penyakit Hipertiroidisme (P002) dari gejala G014, G015 dan G006 yaitu sebesar 96\% dan keyakinan akan terjadinya 
penyakit Hipotiroidisme (P001), Hipertiroidisme (P002) dan Radang Tiroid (P003) secara bersamaan yaitu sebesar 2,4\%.

3. Tentukan nilai keyakinan M5 dan M6 untuk menghasilkan M7.

Fakta 4 : G011 (M6) merupakan gejala penyakit dari Hipotiroidisme (P001) dan Hipertiroidisme (P002), maka dapat ditentukan nilai belief dan plausibility berikut:

$\begin{array}{ll}\text { Nilai belief M6(G011) } & =0,6 \\ \text { Nilai Plausibility M6( } \theta) & =1-0,6=0,4\end{array}$

Selanjutnya hitung densitas baru untuk kombinasi M7 seperti pada Tabel 7:

Tabel 7. Densitas Baru untuk M7

\begin{tabular}{lll}
\hline & M6 $\{$ P001, P002 $\} \mathbf{0 , 6}$ & M6 $\{\boldsymbol{\theta}\} \mathbf{0 , 4}$ \\
\hline M5 $\{$ P002 $\}$ 0,96 & $\{\mathrm{P} 002\} 0,576$ & $\{\mathrm{P} 002\} 0,384$ \\
M5 $\{$ P001, P002, P003 $\}$ 0,024 & $\{\mathrm{P} 001, \mathrm{P} 002\} 0,014$ & $\{\mathrm{P} 001, \mathrm{P} 002, \mathrm{P} 003\} 0,0096$ \\
M5 $\{\boldsymbol{\theta}\} \mathbf{0 , 0 1 6}$ & $\{\mathrm{P} 001, \mathrm{P} 002\} 0,0096$ & $\{\theta\} 0,0016$ \\
\hline
\end{tabular}

Maka selanjutnya dapat dihitung tingkat keyakinan M7 sebagai berikut:

Nilai belief $M 7\{P 002\}=\frac{(0.576+0.384)}{1-0}=0.96$

Nilai belief $M 7\{P 001, P 002\}=\frac{(0.014+0.0096)}{1-0}=0.01104$

Nilai belief $M 7\{P 001, P 002, P 003\}=\frac{(0.0096)}{1-0}=0.0096$

Nilai Plausibility $M 7\{\theta\} \quad=\frac{(0.0064)}{1-0}=0.0064$

Maka nilai keyakinan terhadap penyakit Hipertiroidisme (P002) dari gejala G014, G015, G006 dan G011 yaitu sebesar 96\% dan keyakinan akan terjadinya penyakit Hipotiroidisme (P001), Hipertiroidisme (P002)secara bersamaan yaitu sebesar $1,1 \%$ serta keyakinan terjadinya penyakit Hipotiroidisme (P001), Hipertiroidisme (P002) dan Radang Tiroid (P003) secara bersamaan yaitu sebesar $0,96 \%$.

4. Tentukan nilai keyakinan M7 dan M8 untuk menghasilkan M9.

Fakta 4 : G016 (M8) merupakan gejala penyakit dari Hipertiroidisme (P002), maka dapat ditentukan nilai belief dan plausibility berikut:

Nilai belief M8(G016) $\quad=0,6$

Nilai Plausibility $\operatorname{M} 8(\theta) \quad=1-0,6=0,4$

Selanjutnya hitung densitas baru untuk kombinasi M9 seperti pada Tabel 8:

Tabel 8. Densitas Baru untuk M9

\begin{tabular}{lll}
\hline & M8 $\{$ P002 $\} \mathbf{~ 0 , 6}$ & M8 $\{\boldsymbol{\theta}\} \mathbf{0 , 4}$ \\
\hline M7 $\{$ P002\} 0,96 & $\{\mathrm{P} 002\} 0,576$ & $\{\mathrm{P} 002\} 0,384$ \\
M7 $\{$ P001,P002 $\mathbf{0 , 0 1 1 0 4}$ & $\{\mathrm{P} 002\} 0,0066$ & $\{\mathrm{P} 001, \mathrm{P} 002\} 0,0044$ \\
M7 $\{$ P001, P002, P003\} 0,0096 & $\{\mathrm{P} 002\} 0,0057$ & $\{\mathrm{P} 001, \mathrm{P} 002, \mathrm{P} 003\} 0,0038$ \\
M7 $\{\boldsymbol{\theta}\} \mathbf{0 , 0 1 6}$ & $\{\mathrm{P} 002\} 0,00384$ & $\{\theta\} 0,00256$ \\
\hline
\end{tabular}

Maka selanjutnya dapat dihitung tingkat keyakinan M9 sebagai berikut: 
Hal : $1-14$

NilaibeliefM9 $\{P 002\}=\frac{(0.576+0.384+0,0066+0,0057+0,0038)}{1-0}=0.976$

Nilai belief $M 9\{P 001, P 002\}=\frac{(0.0044)}{1-0}=0.0044$

Nilai belief $M 9\{P 001, P 002, P 003\}=\frac{(0.0038)}{1-0}=0.0038$

Nilai Plausibility $M 9\{\Theta\}$ $=\frac{(0.00256)}{1-0}=0.00256$

Maka nilai keyakinan terhadap penyakit Hipertiroidisme (P002) dari gejala G014, G015, G006, G011 dan G016 yaitu sebesar 97,6\% dan keyakinan akan terjadinya penyakit Hipotiroidisme (P001), Hipertiroidisme (P002) secara bersamaan yaitu sebesar $0,44 \%$ serta keyakinan ternyadinya penyakit Hipotiroidisme (P001), Hipertiroidisme (P002) dan Radang Tiroid (P003) secara bersamaan yaitu sebesar $0,38 \%$.

Seluruh fakta dari gejala pasien telah di uji, maka dapat ditentukan nilai keyakinan tertinggi dari penyakit. Dari proses metode Dempster Shafer diatas dihasilkan penyakit Hipertiroidisme sebagai penyakit yang dialami pasien dengan nilai keyakinan 97,6\%.

\subsection{User Interface Sistem Pakar Penyakit Tiroid}

Setelah melakukan pengujian metode Dempster Shafer, selanjutnya membangun sistem pakar dan mengimplementasikan metode kedalam sistem pakar. Adapun desain interface yang telah dirancang dalam sistem pakar ini dalapat dilihat sebagai berikut :

a. Halaman Utama

Halaman utama merupakan halaman awal dari sistem pakar, adapun halaman utama dari sistem pakar dapat dilihat pada Gambar 4 berikut:

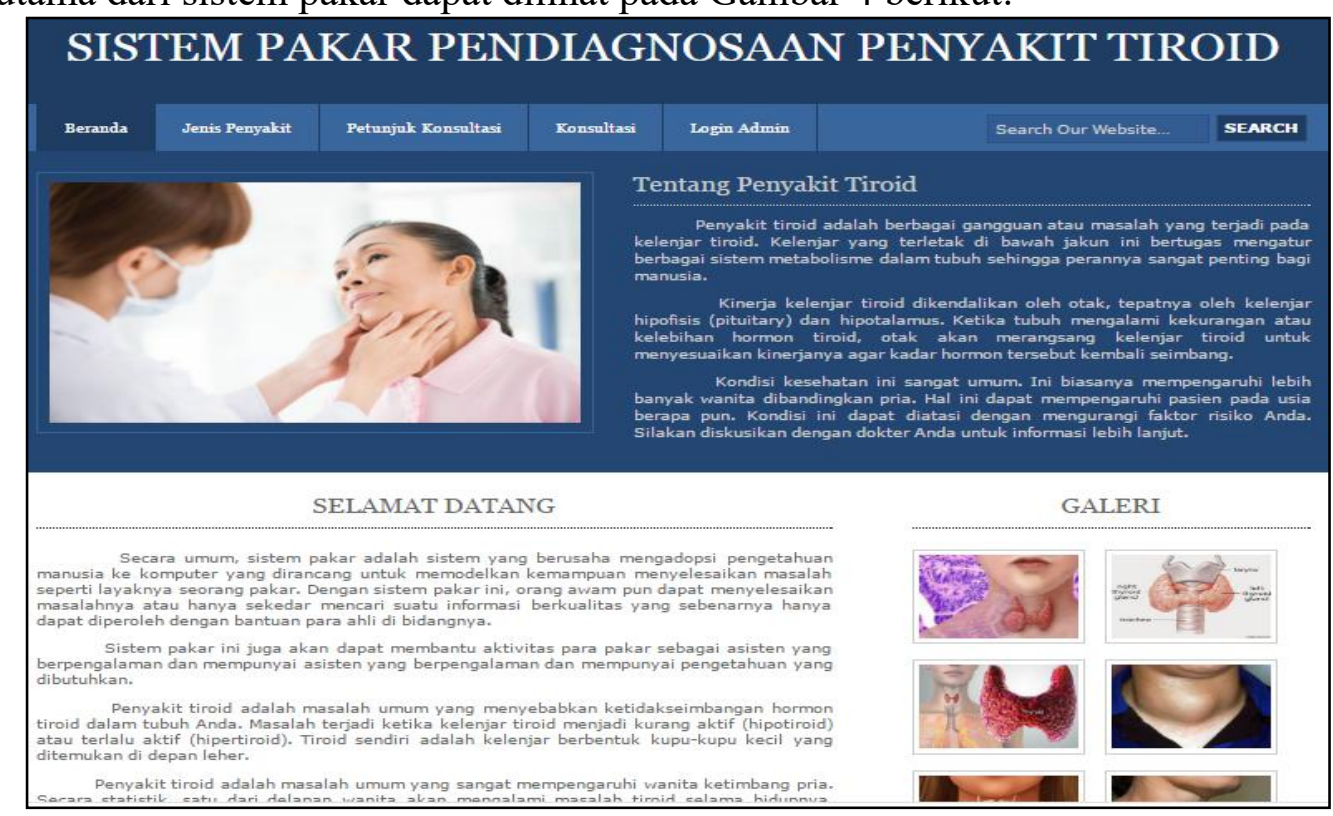

Gambar 4. Halaman Utama Sistem

b. Halaman Konsultasi Penyakit

Halaman konsultasi merupakan halaman yang digunakan oleh user untuk memilih gejala-gejala penyakit tiroid yang dirasakan melalui centang Checkbox. 
Apabila user merasakan gejala yang ada pada list gejala sistem, maka user akan mencentang Checkbox tersebut. Halaman konsultasi dapat dilihat pada Gambar 5 berikut:

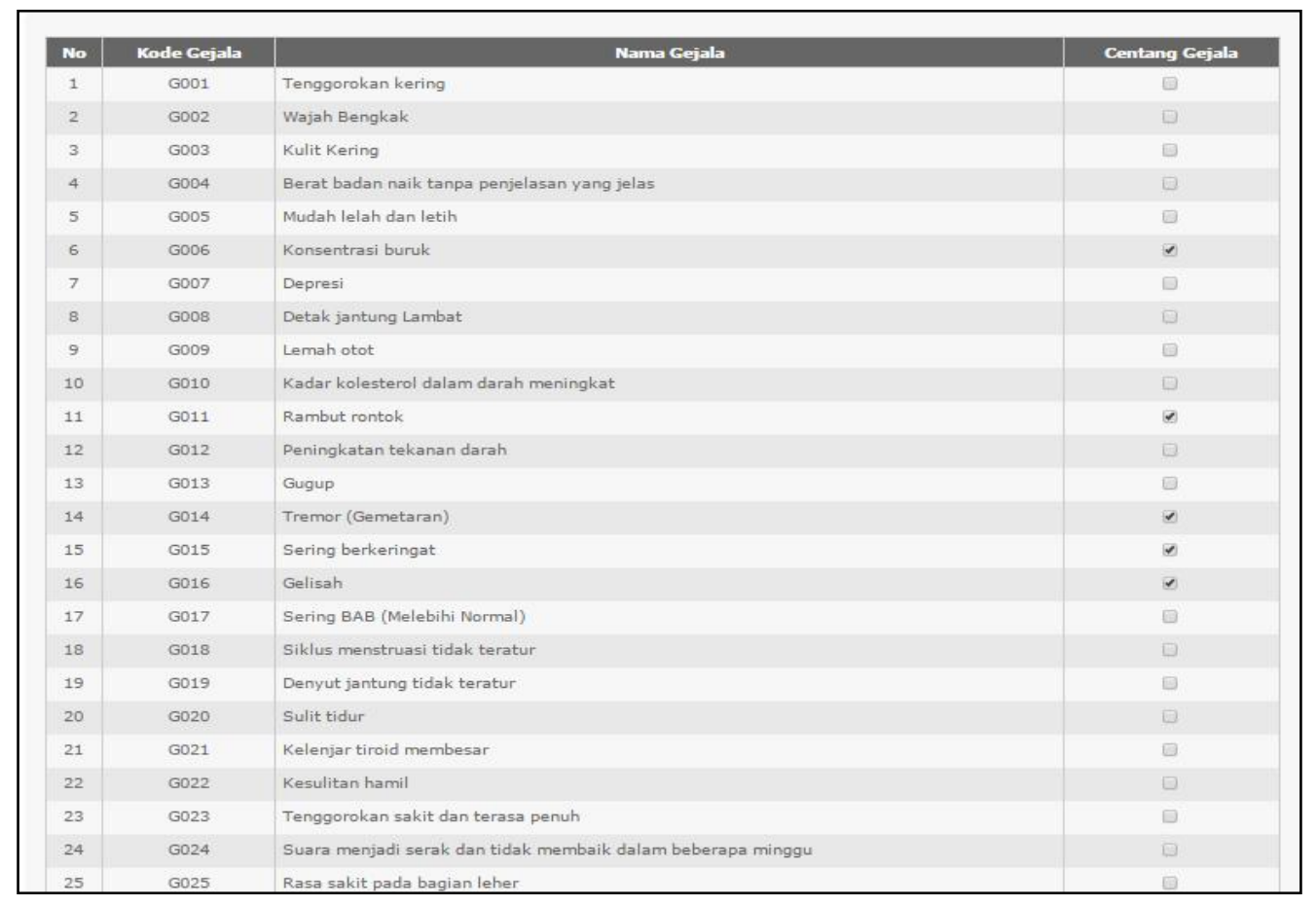

Gambar 5. Halaman Konsultasi Penyakit

c. Halaman Hasil Diagnosa

Halaman hasil diagnosa merupakan halaman yang menampilkan hasil diagnosa dari konsultasi uang dilakukan oleh pasien. Halaman hasil diagnosa dapat dilihat pada Gambar 6 berikut:

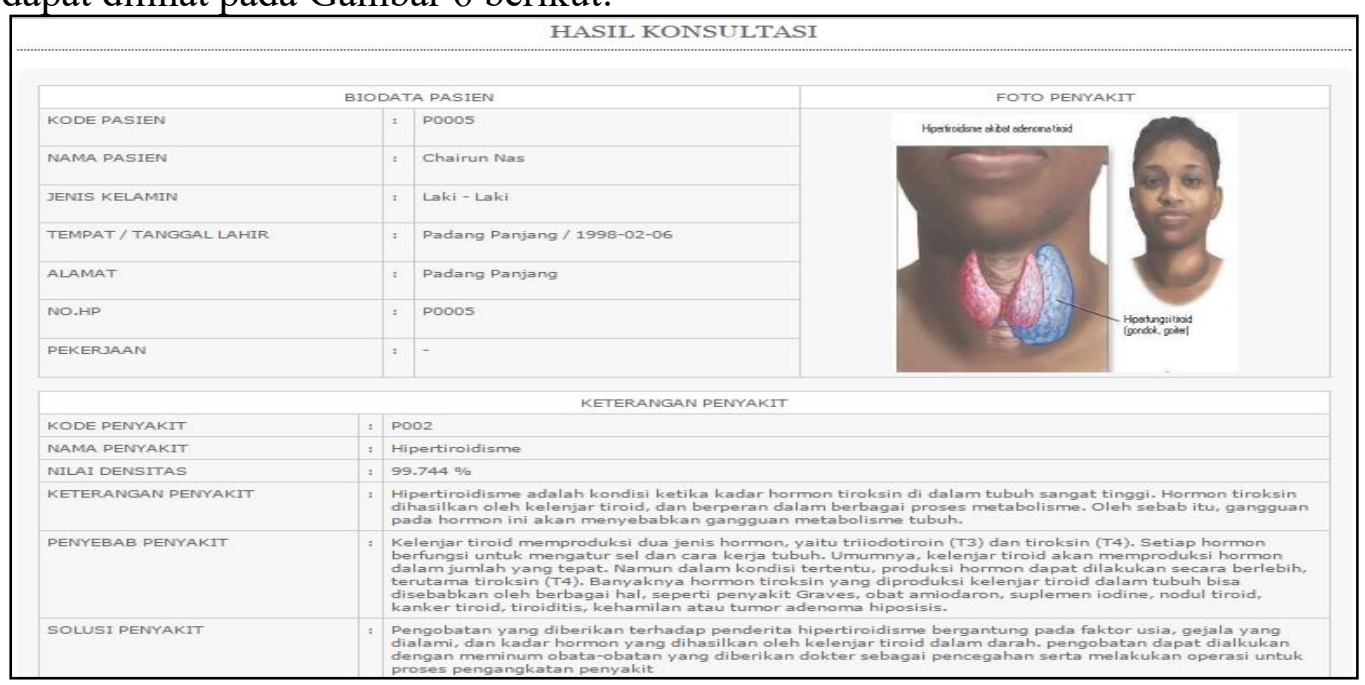

Gambar 6. Hamalan Hasil Diagnosa 


\section{SIMPULAN}

Berdasarkan pembahasan yang telah dilakukan, maka dapat ditarik kesimpulan dan saran sebagai berikut:

\section{a. Simpulan}

Metode Dempster Shafer telah dapat melakukan analisa data-data yang diperoleh sehingga dapat mendiagnosa penyakit tiroid yang dialami oleh pasien. Dari hasil pengujian yang dilakukan, diperoleh penyakit tiroid jenis Hipertiroidisme dengan tingkat keyakinan sebesar 97,6\%. Maka dengan tingkat keyakinan tersebut, metode Dempster Shafer dapat diterapkan dalam sistem pakar untuk mendiagnosa penyakit, serta membantu dokter spesialis dalam penanganan penyakit tiroid.

\section{b. Saran}

Untuk penelitian selanjutnya, dapat dilakukan pengembangan terhadap penyakit dan gejala penyakit tiroid yang lebih kompleks, sehingga dapat menghasilkan diagnosa penyakit yang lebih luas. Serta mengembangkan metode dalam sistem pakar yang dapat dikombinasikan dengan menggunakan metode lainnya.

\section{DAFTAR PUSTAKA}

[1] Khosravi,M., Yazdanshenas, M. dan Nemati,M,H.(2015).“Design Of An Expert System For Diagnosis Of Thyroid Cancer” Science Joirnal (CSJ), Volume 36, Nomor 3, ISSN $1300-1949$.

[2] Putra,A.,Ernawati. dan Erlansari,A.(2017)."Sistem Pakar Diagnosa Penyakit Tiroid Menggunakan Metode Naive Bayes Berbasis Android" Jurnal Rekursif, Volume 5, Nomor 3, ISSN $2303-0755$.

[3] Kartika,B, P. dan Puspitasari,D.(2015)."Sistem Pakar Diagnosa Penyakit Ginjal Menggunakan Metode Dempster Shafer" Prosiding Seminar Informatika Aplikatif Polinema, ISSN 2460 - 1160.

[4] Minardi,J.(2016).“Sistem Pakar Untuk Diagnosa Penyakit Kehamilan Menggunakan Metode Dempster Shafer dan Decission Tree” Jurnal SIMETRIS, Volume 7, Nomor 1, ISSN $2252-4983$.

[5] Sinaga,M, D. dan Sembiring,N, S.(2016).“Penerapan Metode Dempster Shafer Untuk Mendiagnosa Penyakit Dari Akibat Bakteri Salmonella" Cogito Smart Journal, Volume 2, Nomor 2.

[6] Nugraha,D. dan Winiarti,S.(2014)."Pengembangan Media Pembelajaran Sistem Pelacakan Pada Mata Kuliah Kecerdasan Buatan Berbasis Multimedia" Jurnal Sarjana Teknik Informatika,Volume 2, Nomor 1, e-ISSN 2338 - 5197.

[7] Wijaya,E.(2014).“Analisis Penggunaan Algoritma Breadth First Search Dalam Konsep Artificial Inteligence" Jurnal TIME,Volume2, Nomor2.

[8] Supartini,W. dan Hindarto.(2016)."Sistem Pakar Berbasis Web Dengan Metode Forward Chaining Dalam Mendiagnosis Dini Penyakit Tuberkolosis di Jawa Timur" KINETIK, Volume 1, Nomor 3, ISSN 2503 - 2259.

[9] Alfatah,A, M., Arifudin, R. dan Muslim,M, A.(2018).“Implementation of Decission Tree And Dempsters Shafer on Expert System for Lung Disease Diagnosis" Scientific Journal of Information, Volume5, Nomor1, ISSN 2407 - 7658.

[10] Yunita,W. dan Latifah,L.(2016). "Kecemasan dan Gangguan Fungsi Tiroid Pada Wanita Usia Subur" MGMI, Volume 7, Nomor 2, DOI: 10.22435mgmi.v7i2.6017.107116. 
[11] Ionita,I. dan Ionita,L.(2016)."Prediction of Thyroid Disease Using Data Mining Technique" BRAIN, Volume 7, Nomor 3, ISSN 2068-0473.

[12] Keles,A. dan Keles,Ay.(2008). "Expert System For Thyroid Diseases Diagnosis" Expert System With Applications, Volume 1, Nomor 34, DOI: 10.1016/j.eswa.2006.09.028. 